ARTIKEL PENELITIAN

\title{
Scoping Review: Hubungan Stres Kerja dengan Hipertensi pada Tenaga Kesehatan
}

\author{
Fani Sugiarti, ${ }^{1}$ Lia Marlia Kurniawati, ${ }^{2}$ Yuli Susanti ${ }^{3}$ \\ ${ }^{1}$ Program Studi Pendidikan Dokter \\ ${ }^{2}$ Departemen Ilmu Kesehatan Anak \\ 32Departemen Ilmu Kesehatan Masyarakat, Fakultas Kedokteran, Universitas Islam Bandung
}

\begin{abstract}
Abstrak
Stres merupakan suatu respons adaptif melalui karakteristik individu dan atau proses psikologis secara langsung terhadap tindakan, situasi dan kejadian eksternal. Stres kerja merupakan kondisi ketegangan yang dapat memengaruhi cara berpikir, emosi, dan kondisi individu. Hipertensi merupakan salah satu masalah kesehatan utama di Indonesia maupun di dunia. Hipertensi dapat terjadi karena berbagai faktor, antara lain stres, obesitas, merokok, konsumsi alkohol, usia, jenis kelamin, dan genetik. Stres merupakan kondisi yang dapat dialami semua orang. Tenaga kesehatan adalah setiap orang yang mengabdikan diri dalam bidang kesehatan. Tenaga kesehatan merupakan salah satu di antara lima belas belas profesi dengan tingkat stres paling tinggi. Kondisi stres dapat menimbulkan sakit kepala, insomnia serta salah satunya hipertensi. Penelitian bertujuan untuk mengetahui ada tidaknya hubungan stres kerja dengan hipertensi pada tenaga kesehatan. Pencarian sistematis dilakukan melalui pencarian database elektronik, yaitu PubMed, Science Direct, Proquest, Google Scholar, dan SpringerLink. Artikel yang di-review adalah yang berkaitan dengan stres kerja dan hipertensi pada tenaga kesehatan. Dari pencarian kata kunci yang ditemukan pada kelima database dicatat pada diagram prisma sebanyak 2.925 artikel dan terdapat 10 artikel yang sesuai untuk direview. Diperoleh hasil bahwa stres kerja berhubungan dengan hipertensi pada tena-ga kesehatan. Kondisi tersebut terjadi karena disfungsi hipotalamus-hipofisis-adrenal dan sistem saraf autonom telah terbukti menjadi sistem pengaturan utama yang terlibat dalam proses terjadinya hipertensi.
\end{abstract}

Kata kunci: Hipertensi, stres kerja, tenaga kesehatan

\section{Relationship of Job Stress with Hypertension in Health workers: Scoping Review}

\begin{abstract}
Stress is an adaptive response, through individual and/or direct psychological processes to external actions, situations and events. Mental job stress that can affect ways of thinking, emotions, and individual conditions. Hypertension is one of the main health problems in Indonesia and also in the world. Hypertension can occur due to various factors, including stress, obesity, smoking, alcohol consumption, age, gender and genetics. Stress is a condition that can serve everyone. A health worker is anyone who devotes himself to the health sector. The health worker is one of fifteen high-stress professions. Stress conditions can cause headaches, insomnia and one of them hypertension. This study aims to determine whether there is a relationship between job stress and hypertension among health workers. Systematic searches are carried out through electronic database searches, namely PubMed, Science Direct, Proquest, Google Scholar, SpringerLink. The articles reviewed were those related to job stress and hypertension in health workers. From the keyword search found in the five databases, there were 2,925 articles on the prism diagram and there were 10 articles that were suitable for review. The results show that job stress is related to hypertension in health workers. This condition occurs because the dysfunction of the hypothalamus-pituitaryadrenal and autonomic nervous system has been shown to be the main regulatory system involved in the process of hypertension.
\end{abstract}

Keywords: Health workers, hypertension, job stress

Received: 8 ...; Revised: ...; Accepted: ...; Published: ...

Koresponden: Fani Sugiarti. Prodi Pendidikan Sarjana Kedokteran, Fakultas Kedokteran, Universitas Islam Bandung, Jalan Tamansari No. 22, 40116, Kota Bandung, provinsi Jawa Barat, Hp: 087771500561 Email: fanisugiart@gmail.com 


\section{Pendahuluan}

Hipertensi adalah suatu kondisi ditandai dengan peningkatan tekanan darah sistolik (TDS) dan tekanan darah diastolik (TDD) $\geq 140 / 90 \mathrm{mmHg}$. Dalam jangka yang lama peningkatan tekanan darah kronis akan menyebabkan peningkatan risiko kejadian kardiovaskular, serebrovaskular, dan renovaskular. ${ }^{1}$

World Health Organization (WHO) tahun 2015 memperlihatkan sekitar 1,13 miliar orang di dunia mengidap hipertensi. Jumlah orang yang mengidap hipertensi terus meningkat pertahunnya. Diperkirakan tahun 2025 terdapat 1,5 miliar orang yang terkena hipertensi, dan diperkirakan pertahunnya terdapat 9,4 juta orang tewas karena kejadian hipertensi serta komplikasinya. Pada 20151 dari 4 pria dan 1 dari 5 wanita terdiagnosis hipertensi. ${ }^{2}$ Prevalensi hipertensi secara keseluruhan mencapai $22 \%$ meliputi wilayah Amerika sebanyak 18\%, Afrika sebanyak 17\%, Asia Tenggara sebanyak 25\%, Eropa sebanyak 23\%, Mediterania Timur sebanyak 26\%, Pasifik Barat sebanyak $18 \% .^{3}$

Riskesdas 2018 menyebutkan jumlah kasus hipertensi di negara Indonesia sebanyak 63.309.620 orang, dan angka kematian di Indonesia akibat hipertensi sebanyak 427.218 kematian. ${ }^{4,5}$ Hipertensi dipengaruhi dua jenis faktor risiko yaitu, yang tidak dapat dikendalikan seperti usia, jenis kelamin, dan genetik sedangkan faktor yang dapat dikendalikan yaitu obesitas, konsumsi alkohol, kebiasaan merokok dan stres.

Stres kerja merupakan masalah yang penting untuk dibahas. Hampir semua orang di dalam kehidupan mereka mengalami stres berhubungan dengan pekerjaan mereka. Hal ini dapat dipengaruhi karena tuntutan kerja yang terlalu banyak (bekerja terlalu keras dan sering kerja lembur) dan jenis pekerjaan yang harus memberikan penilaian atas penampilan kerja bawahannya atau pekerjaan yang menuntut tanggung jawab bagi manusia. ${ }^{6}$ individu yang mengalami stres kerja tinggi juga mengalami hipertensi, kejadiannya sekitar $61,8 \%$ dan lebih banyak dialami oleh pria dibandingkan wanita. ${ }^{7}$

Rumah sakit merupakan salah satu penyelenggara pelayanan kesehatan perorangan. Pelayanan kesehatan oleh rumah sakit meliputi pelayanan rawat inap, rawat jalan, dan gawat darurat. ${ }^{8}$ Profesi tenaga kesehatan merupakan salah satu profesi paling menantang yang disebabkan oleh adanya tuntutan untuk melibatkan fisik dan mental sang individu. ${ }^{9}$ profesi ini akan ditemukan lebih menantang dikarenakan kurangnya sumber daya. Asia yang merupakan negara yang memiliki jumlah populasi tinggi. ${ }^{10}$ Survei tersebut menunjukkan jika profesi yang terkait dengan penyediaan layanan kesehatan merupakan salah satu diantara lima belas belas profesi dengan tingkat stres paling tinggi. ${ }^{11}$

Pada survei menunjukan $88 \%$ dari 2.005 dokter mengidentifikasikan diri mereka pada tingkat stres yang sedang hingga parah sehari-harinya. Survey kepada 86.000 responden karyawan dan pekerja. ${ }^{12}$ Stress Kerja pada dokter di Rumah Sakit Umum Bethesda GMIM Tomohon terdapat sebanyak 13 orang $(38,2 \%)$ dan berat sebanyak 21 orang $(61,8 \%)$ dari total seluruhnya 34 dokter.(9) Perawat sebagai tenaga kesehatan yang selalu kontak dan berhadapan pertama kali dengan pasien,perawat harus selalu cepat, tepat, dan cermat untuk mencegah kematian dan kecacatan. ${ }^{13}$ Profesi keperawatan berpotensi mengalami stress di tempat kerja dan menghadapi tekanan di lingkungan medis yang diakibatkan berbagai stressor. ${ }^{14}$ Jika seorang perawat mengalami stres ialah dapat mengganggu interaksi sosialnya, baik itu dengan rekan kerja, dokter maupun pasien. Profesi perawat mendapati profesi tingkat stress yang lebih tinggi dari pada 6 kelompok professional lainnya yaitu dokter, insinyur, agen asuransi jiwa, pengacara, perawat dan guru. ${ }^{15}$ sehinggap pada penelitian ini untuk mengetahui ada tidaknya hubungan stres kerja dengan hipertensi pada tenaga kesehatan.

\section{Metode}

Jenis penelitian yang digunakan adalah scoping review. Dilakukan review pada artikel-artikel penelitian yang terpilih dengan beberapa langkah sebagai berikut:

1. Pencarian data dengan pencarian pada tiga database, yaitu Pubmed, SpringeLink, Science Direct, ProQuest dan Google Scholar dengan menggunakan kata kunci (work stress and occupational stress and job stress hypertension and nurse and health worker).

2. Skrining data dengan cara memilih artikel yang sesuai dengan judul penelitian dan sesuai dengan kriteria inklusi, yaitu: 1) 1. Jurnal yang berasal dari nasional dan internasional diakses melalui database; 2) sesuai dengan kata kunci; 3) artikel diterbitkan kurang dari 10 tahun; 4) bisa diakses secara full text; 5) artikel berbahasa Indonesia maupun Inggris.

3. Penilaian kualitas (kelayakan) disesuaikan dengan kriteria eksklusi, yaitu: 1) artikel yang tidak dapat diakses; 2) Duplikasi artikel; 3) Artikel yang bukan penelitian. Disesuaikan juga dengan kriteria PICOS: Population (tenaga kesehatan (dokter dan perawat)), Exposure (stres ditempat kerja), Comparation (Kelompok kontrol hipertensi yang memenuhi syarat adalah yang tidak terpapar stress kerja), Outcome (Hipertensi), dan Study (observational study: kohortdan cross-sectional).

4. Hasil pencarian data didapatkan sepuluh artikel yang di-review dan disajikan dalm bentuk diagram PRISMA pada gambar 1 .

\section{Gambar 1 Diagram PRISMA}




\section{Hasil}

Hasil artikel menunjukkan terdapat 10 laporan penelitian yang dapat digunakan untuk menjawab rumusan masalah penelitian ini. Artikel penelitian yang digunakan pada scoping review ini merupakan artikel penelitian yang berasal dari jurnal nasional dan internasional, berusia $<10$ tahun. Dijalaskan dalam tabel.1

\begin{tabular}{|c|c|c|c|c|c|}
\hline Judul/Peneliti & Tujuan & $\begin{array}{c}\text { Desain } \\
\text { penelitian }\end{array}$ & $\begin{array}{c}\text { Metode } \\
\text { pengukuran }\end{array}$ & Tehnik analisis & hasil \\
\hline $\begin{array}{l}\text { Blood pressure and } \\
\text { working conditions in } \\
\text { hospital nurses and } \\
\text { nursing assistants. The } \\
\text { ORSOSA study (16) } \\
\text { 2O11 } \\
\text { Perancis }\end{array}$ & $\begin{array}{l}\text { Analisis hubungan } \\
\text { antara tekanan } \\
\text { arteri (BP) dan } \\
\text { efaktor risiko pada } \\
\text { perawat rumah } \\
\text { sakit. }\end{array}$ & $\begin{array}{l}\text { cohort study } \\
2307 \text { perawat } \\
\text { dan } 1530 \\
\text { asisten } \\
\text { perawat }\end{array}$ & $\begin{array}{l}\text { Kuesioner NWI- } \\
\text { EO. Tekanan darah } \\
\text { diukur di tempat } \\
\text { kerja setelah } 5,6 \text { dan } \\
7 \text { menit istirahat }\end{array}$ & $\begin{array}{l}\text { Koefisien korelasi } \\
\text { Pearson dan regresi } \\
\text { linier } \\
\text { uji Wald. } \\
\text { Stata v.11 lunak- } \\
\text { ware (StataCorp LP, } \\
\text { College Station, TX, } \\
\text { USA) }\end{array}$ & $\begin{array}{l}\text { Tekanan darah sistolik } \\
\text { dan diastolik berhubungan } \\
\text { secara bermakna dengan } \\
\text { usia dan berat badan } \\
\text { berlebihan. Hubungan tim } \\
\text { yang buruk adalah dimensi } \\
\text { NWI-EO yang paling } \\
\text { signifikan dengan TD. }\end{array}$ \\
\hline $\begin{array}{l}\text { Psychosocial stress } \\
\text { and hypertension in } \\
\text { nursing staff (17) } \\
2015 \\
\text { Brazil }\end{array}$ & $\begin{array}{l}\text { Menggambarkan } \\
\text { prevalensi } \\
\text { systemic arterial } \\
\text { hypertension } \\
\text { (SAH), hubungan } \\
\text { stres psikososial } \\
\text { dan hipertensi arteri } \\
\text { sistemik pada staf } \\
\text { perawat. }\end{array}$ & $\begin{array}{l}\text { Cross- } \\
\text { sectional } \\
388 \\
\text { i }\end{array}$ & $\begin{array}{l}\text { kuesioner job stress } \\
\text { scale (psychosocial } \\
\text { stress-exposure) } \\
\text { tervalidasi. Dilakukan } \\
\text { pengukuran } \\
\text { topometri (berat } \\
\text { badan, tinggi badan, } \\
\text { lingkar pinggang dan } \\
\text { pinggul) dan tekanan } \\
\text { darah diperiksa. }\end{array}$ & $\begin{array}{l}\text { binary logistic } \\
\text { regression (Enter } \\
\text { Method), Odds } \\
\text { Ratio uji Hosmer- } \\
\text { Leneshow untuk } \\
\text { memverifikasi } \\
\text { model penyesuaian } \\
\text { terbaik (closest to } \\
\text { 1.o). }\end{array}$ & $\begin{array}{l}\text { Tidak ada hubungan } \\
\text { antara hipertensi dan stres } \\
\text { psikososial. Prevalensi } \\
\text { hipertensi stadium I, } \\
\text { terkait dengan usia, warna } \\
\text { kulit yang dilaporkan } \\
\text { sendiri ,tidak putih, dan } \\
\text { dengan lingkar pinggang } \\
\text { yang tidak memadai. }\end{array}$ \\
\hline $\begin{array}{l}\text { Self-perceived } \\
\text { occupational stress } \\
\text { and blood pressure } \\
\text { profile of nurses from } \\
\text { government hospitals } \\
\text { (18) } \\
\text { 2016 } \\
\text { India }\end{array}$ & $\begin{array}{l}\text { Menentukan } \\
\text { stres kerja yang } \\
\text { dirasakan sendiri } \\
\text { dan profil tekanan } \\
\text { darah perawat } \\
\text { dari rumah sakit } \\
\text { pemerintah di } \\
\text { Delhi. }\end{array}$ & $\begin{array}{l}\text { Cross } \\
\text { sectional } \\
100 \text { perawat }\end{array}$ & $\begin{array}{l}\text { questionnaire-cum- } \\
\text { interview schedule } \\
\text { dan menggunakan } \\
\text { sphygmomanometer } \\
\text { klasifikasi Joint } \\
\text { National Committee } \\
\text { on Prevention, } \\
\text { Detection, and } \\
\text { Treatment of High } \\
\text { Blood Pressure } \\
\text { (JNC-7) }\end{array}$ & $\begin{array}{l}\text { Data dianalisis } \\
\text { dengan software } \\
\text { Statistical Package } \\
\text { for Social Sciences } \\
\text { (SPSS) version 20.0 }\end{array}$ & $\begin{array}{l}\text { Stres kerja dialami oleh } \\
70 \% \text {. Sekitar } 40 \% \text { dan } \\
\text { 13,8\% subjek berada dalam } \\
\text { kategori prehipertensi } \\
\text { dan hipertensi stadium } 1 . \\
\text { karena profil pekerjaan } \\
\text { yang menuntut dan stres } \\
\text { yang diakibatkannya } \\
\text { mungkin memiliki tingkat } \\
\text { tekanan darah yang tidak } \\
\text { normal. }\end{array}$ \\
\hline
\end{tabular}

The Influence of Domestic Overload on the Association between Job Strain and Ambulatory Blood Pressure among Female Nursing Workers. (19) 2013 Brazil

Menilai apakah job Cross strain berkaitan sectional dengan pengukuran 175 perawat tekanan darah rawatwanita mempertimbangkan pengukuran peran potensial pekerjaan rumah tangga. jalan 24 jam dengan

memakai monitor (ANOVA) dan uji Stres psikososial tempat tekanan darah rawatchi-square Pearson. kerja tidak berhubungan jalan $(A B P M)$ selamaAnalisis multivariat secara signifikan dengan 24jam. Job strain varians (MANOVA). tekanan darah rawat jalan atau stres yang Semua analisis pada seluruh kelompok dirasakan di tempat dilakukan dengan pekerja. Tidak bekaitan kerja diukur dengan menggunakan SPSS dengan timbulnya Demand-Control v.19.0. $\quad$ hypertensi yang dipicu Questionnaire oleh peningkatan tekanan darah terus menerus. Pada penelitian ini perempuan menunjukan interaksi penting antara pekerjaan rumah tangga dan job strain.

\begin{tabular}{|c|c|c|c|c|c|}
\hline $\begin{array}{l}\text { Work related } \\
\text { stress perception \& } \\
\text { hypertension among } \\
\text { Nurses working } \\
\text { at selected icus in } \\
\text { sgpgims, lucknow, } \\
\text { india (2O) } \\
2019\end{array}$ & $\begin{array}{l}\text { Untuk melihat } \\
\text { hubungan persepsi } \\
\text { terkait stres kerja } \\
\text { \& hipertensi antara } \\
\text { perawat yang } \\
\text { bekerja di ICU }\end{array}$ & $\begin{array}{l}\text { Cross- } \\
\text { sectional } \\
60\end{array}$ & $\begin{array}{l}\text { Expanded Nursing } \\
\text { Stress Scale } \\
\text { developed by French. } \\
\text { sphygmomanometer } \\
\text { and JNC7 }\end{array}$ & $\begin{array}{l}\text { Dianalisis } \\
\text { menggunakan } \\
\text { statistik deskriptif } \\
\text { dan inferensial } \\
\text { berdasarkan tujuan } \\
\text { penelitian serta } \\
\text { menggunakan chi } \\
\text { square. }\end{array}$ & $\begin{array}{l}\text { Dianalisis menggunakan } \\
\text { statistik deskriptif dan } \\
\text { inferensial berdasarkan } \\
\text { tujuan penelitian serta } \\
\text { menggunakan chi square. }\end{array}$ \\
\hline
\end{tabular}




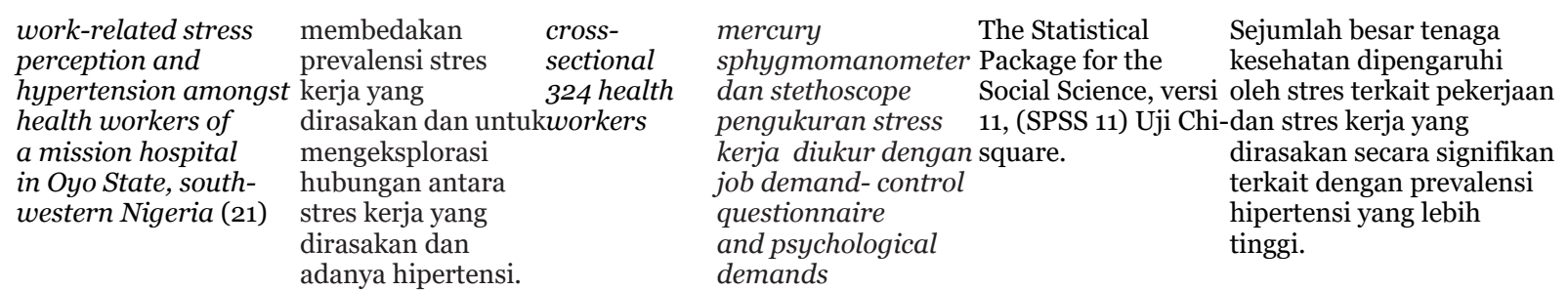

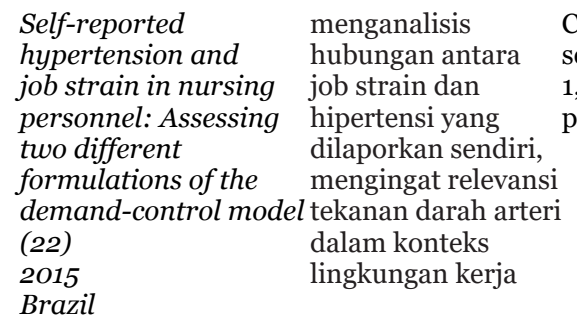

Cross- ketegangan pekerjaan Chi-square test. sectional dinilai menurut dua model regresi 1,307 perawat formulasi demand- logistik. perempuan control model. Prevalence ratio Hipertensi dilaporkan sendiri dinilai dengan riwayat hipertensi.
(PR) analysis

di kalkulasi menggunakan generalized linear models with binomial dis- tribution dan Poisson link (robust estimator)
Hipertensi dan Job Strain secara statistik signifikan hanya ketika job strain dievaluasi menggunakan the demand-control model..

$\begin{array}{ll}\text { Job strain and arterial menganalisis } \\ \text { hypertension in } & \text { hubungan antara } \\ \text { nursing professionals } & \text { ketegangan } \\ \text { from the municipal } & \text { kerja (job strain) } \\ \text { healthcare network in } & \text { dan hipertensi } \\ \text { Belo Horizonte, Minas } & \text { arteri (Arterial } \\ \text { Gerais, Brazil (23) } & \text { Hypertension) } \\ \text { 2016 } & \text { pada profesional } \\ \text { Brazil } & \text { keperawatan dari } \\ & \text { jaringan perawatan } \\ & \text { kesehatan kota Belo } \\ & \text { Horizonte } \\ \text { Psychosocial and } & \text { Menguji hubungan } \\ \text { organizational } & \text { longitudinal } \\ \text { workfactors and } & \text { independen yang } \\ \text { incidence of arterial } & \text { menghubungkan } \\ \text { hypertension among } & \text { kejadian 2 tahun } \\ \text { female healthcare } & \text { hipertensi arteri } \\ \text { workers: results of } & \text { dengan stresor } \\ \text { the Organisation } & \text { kolektif di tingkat } \\ \text { des Soinset Sanedes } & \text { unit kerja. } \\ \text { Soignantscohort(24) } & \\ \text { 2014 } & \\ \text { Prancis } & \\ \text { Job Stressors among } & \text { mengidentifikasi } \\ \text { Female Physicians: } & \text { hubungan antara } \\ \text { Relation to Having a } & \text { stresor kerja dan } \\ \text { Clinical Diagnosis of } & \text { status hipertensi. } \\ \text { Hypertension (25) } & \\ \text { 201o } & \\ \text { Serbia } & \\ & \\ & \\ & \end{array}$

Cross- Strain kerja diukur Pearson's chisectional menggunakan model squared test, dan 273 nursing kontrol-permintaan untuk ordinal professionals secara mandiri. medis penyakit atau penggunaan obat antihipertensi
Job strain $(P R=2,53)$ secara independen terkait dengan arterial hypertension setelah penyesuaian multivariat. squared test dengan Job strain dikaitkan linear trend. dengan arterial Regresi Poisson hypertension.
STATA (StataCorp, Organizational work 2011. Stata factors di tingkat unit Statistical Software: kerja dapat mempengaruhi Release 12. College risiko 2 tahun dari Station, TX: hipertensi arteri secara StataCorp LP.) independen dari faktor with the 'logit', kerja di tingkat pekerja, and 'xtmelogit' BP, usia dan BMI.

\author{
procedures. \\ Work unit level \\ diukur melalui 22- \\ item NWI-EO yan
} registered tervalidasi.

\section{nurses, 796 nursing assistants \\ Cohort study

1091
registered
nurses, 796
nursing
assistants

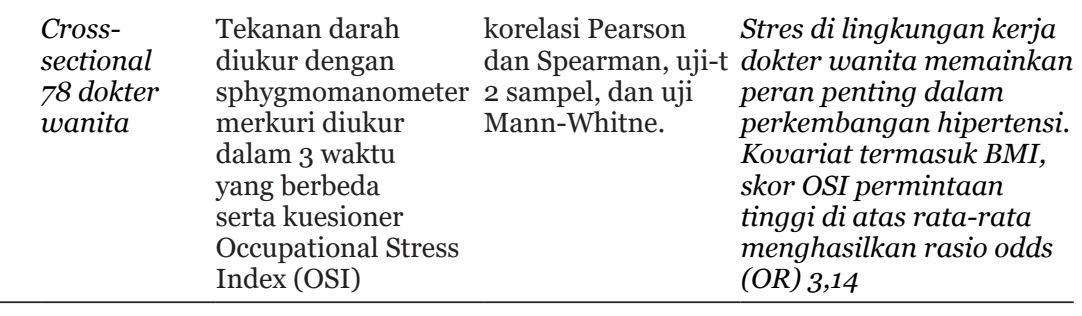

\section{Pembahasan}

Berdasarkan letak geografis artikel yang di-review sebanyak 10 artikel yang diperoleh berasal dari 2 Prancis, 2 India, 4 Brazil, 1 Serbia dan 1 Nigeria. Dua diantaranya menggunakan cohort study dan delapan diantaranya menggunakan cross-sectional. Pada penelitian ini terdapat tujuh artikel yang melaporkan bahwa terdapat hubungan antara stres kerja dengan hipertensi pada tenaga kesehatan.
De Gaudemaris R et al. Studi terhadap 3837 pekerja rumah sakit (2307 perawat dan 1530 asisten perawat), Dimensi NWI-EO yang paling kuat berkorelasi dengan tekanan darah sistolik dan diastolik adalah hubungan tim yang buruk ( $\mathrm{P}<0,01$ untuk keduanya). Untuk perbedaan satu poin dalam skor stres NWI-EO, tekanan darah sistolik lebih tinggi dengan rata-rata $0,2 \mathrm{mmHg}$. Menunjukkan bahwa ada hubungan yang buruk antara stres kerja dan tekanan darah tinggi pada penelitian ini penulis mencantumkan hasil penelitian 
lain yang mendukung artikel tersebut, stres kumulatif di tempat kerja dapat memprediksi suatu peningkatan tingkat BP. ${ }^{16}$

Gupta S, et al. (2011) Pada penelitian disebutkan juga karena profil pekerjaan yang menuntut dan stres yang diakibatkannya memiliki tingkat tekanan darah yang tidak normal. Dalam penelitian ini, ratarata tekanan darah sistolik (SBP) dan tekanan darah diastolik (DBP) perawat masing-masing adalah 116,4 $\mathrm{mmHg}$ dan 76,7 mmHg. Pengkategorian subjek berdasarkan klasifikasi JNC-7 hipertensi pada orang dewasa menunjukkan bahwa lebih dari separuh subjek adalah prehipertensi dan hipertensi stadium 1. Selain hipertensi stres mungkin memiliki efek merugikan secara bertahap pada kesehatan mereka..$^{18}$ penelitian ini dibuktikan oleh penelitian lain yang dikemukakan bahwa stres kerja diantara perawat seringkali dapat menyebabkan kondisi kesehatan kronis seperti diabetes dan penyakit kardiovaskular.Profil tekanan darah para perawat dalam penelitian ini mengungkapkan bahwa lebih dari separuh dari mereka berisiko atau menderita hipertensi. Prevalensi serupa dari hipertensi (13,7\%) dan prehipertensi (42,7\%) dilaporkan oleh Hegde et al.

Merlin C, et al. (2015) Terdapat hubungan yang signifikan antara stress terkait pekerjaan dengan hipertensi. ${ }^{20}$ Studi kohort pendukung dilakukan di universitas Prancis rumah sakit diantara 2.307 perawat dan 1.530 asisten perawat. Hasil menunjukkan bahwa ada hubungan yang buruk antara tekanan darah tinggi dan stres kerja. Studi serupa lainnya dilakukan untuk menilai terjadinya diagnosis hipertensi dan pengobatan hipertensi 494 keperawatan staf rumah sakit darurat di Salvador, Brasil. 494. Wawancara dan pengukuran tekanan darah digunakan untuk mengumpulkan data. Hasil menunjukkan bahwa prevalensi hipertensi $36,4 \%, 18,3 \%$ individu mengabaikan kondisi hipertensi mereka dan 64,2\% mengakuinya namun belum menjalani pengobatan secara rutin. Dari orang-orang yang sedang menjalani pengobatan $69,4 \%$ mengalami peningkatan tekanan darah pemeriksaan. Dari hasil tersebut dapat disimpulkan bahwa stres kerja memiliki dampak potensial pada kesehatan fisik lainnya. ${ }^{20}$

Owolabi AO, et al. (2017) Lebih dari seperempat $(26,2 \%)$ subjek menganggap diri mereka stres di tempat kerja. Kelompok subjek hipertensi terbesar terlihat diantara subjek dengan stres kerja. Sejumlah besar tenaga kesehatan dalam penelitian ini dipengaruhi oleh stres terkait pekerjaan dan stres kerja yang dirasakan secara signifikan terkait dengan prevalensi hipertensi yang lebih tinggi. Beberapa studi internasional mendukung temuan ini. ${ }^{21}$

Adriano MP, et al. (2013) Hasil pada penelitian ini didapatkan antara profesional yang diteliti, 42,1\% adalah perawat dan $57,8 \%$ adalah teknisi atau asisten perawat. Hipertensi arterial didiagnosis pada $16,9 \%$. Jenis kelamin perempuan $(P R=0,56)$, bertambahnya usia ( $p$ dengan tren linier $<0,001$ ), pendapatan rumah tangga dari 4 atau lebih upah minimum $(\mathrm{PR}=0,39)$ dan job strain $(\mathrm{PR}=2,53)$ secara independen terkait dengan arterial hypertension setelah penyesuaian multivariat. Job strain berhubungan dengan arterial hypertension diantara profesional keperawatan dari jaringan perawatan kesehatan kota di Belo Horizonte. ${ }^{23}$ penelitian ini didukung oleh penjelasan penulis mengenai Hubungan yang masuk akal antara ketegangan pekerjaan di tempat kerja dan $\mathrm{AH}$ dijelaskan oleh efek stres psikososial pada dinamika neuroendokrin. Paparan stres psiko-emosional yang konstan menyebabkan hiperaktivitas sistem saraf simpatis dan disfungsi sumbu hipotalamus-hipofisisadrenal, dengan pelepasan noradrenalin dan adrenalin dalam konsentrasi tinggi di celah sinaptik dan di aliran darah, yang masing-masing menyebabkan, di peningkatan jangka panjang dan persisten tekanan darah. $^{23}$

Lamy S, dkk. (2014) Menunjukkan bahwa organizational work factors (OWF) di tingkat unit kerja dapat mempengaruhi risiko 2 tahun dari hipertensi arteri secara independen dari faktor kerja di tingkat pekerja, BP, usia dan BMI. Dalam studi ini, OWF mempengaruhi risiko 2 tahun dari hipertensi arteri melalui efek langsung. ${ }^{24}$

Nedic O,et al. (2010) BMI tinggi adalah faktor risiko paling kuat untuk mengalami hipertensi diantara para dokter dalam penelitian ini. Peneliti menyebutkan total beban stres kerja yang dinilai OSI menunjukkan hubungan independen yang signifikan dengan IMT tinggi diantara dokter wanita. Dengan demikian, dalam perjalanan menuju hipertensi, stresor kerja memainkan peran penting melalui kaitannya dengan obesitas. Stresor di lingkungan kerja dokter wanita tampaknya memainkan peran penting dalam perkembangan hipertensi. ${ }^{25}$

Terdapat satu artikel yang melaporkan perbedaan hasil dengan menggunakan dua metode pengukuran dalam satu penelitian. berdasarkan Portela LF, et al. Hubungan antara hipertensi yang dilaporkan sendiri dan Job Strain secara statistik signifikan hanya ketika job strain dievaluasi menggunakan the demandcontrol model. ${ }^{22}$ Pekerja di kuartil tertinggi dari job strain (istilah hasil bagi) 1,54 kali lebih mungkin untuk melaporkan hipertensi daripada kelompok referensi. Hubungan ini tidak secara statistik signifikan ketika model kontrol permintaan dinilai dengan istilah kuadran. ${ }^{22}$ Diantara studi yang telah mengevaluasi hubungan antara hasil kardiovaskular dan stres kerja psikososial berdasarkan Theorell, et al.Michikawa, et al. menggunakan istilah hasil bagi untuk menilai ketegangan pekerjaan. Keduanya menemukan hubungan yang signifikan antara ketegangan kerja dan penyakit jantung. Rumusan kuadran telah digunakan di banyak studi, misalnya oleh Cesana, et al.dan Guimont, dkk. ${ }^{22}$ yang memeriksa tekanan darah biasa sebagai hasil; dan juga oleh Landsbergis, et al. yang memeriksa pengukuran tekanan darah rawat jalan sebagai hasil, menunjukkan hubungan yang signifikan juga.

Pada penelitian ini juga terdapat dua artikel yang melaporkan bahwa tidak terdapat hubungan antara stres dengan hipertensi pada tenaga kesehatan disebutkan dalam figuereido AE, et al. dan Portela LF, et al.

Figueiredo AE, et al. Pada penelitian terhadap 388 perawat Tidak ada hubungan yang ditemukan antara hipertensi dan stres psikososial. namun ditemukan dengan variabel usia, warna kulit. $^{17}$ sedangkan 
berdasarkan penelitian Portela LF, et al. Tidak ada hubungan yang signifikan antara high job strain dan BP yang terdeteksi. Stres psikososial tempat kerja tidak berhubungan secara signifikan dengan tekanan darah rawat jalan pada seluruh kelompok pekerja. Pada penelitian ini hanya perempuan yang terpapar secara bersamaan dengan pekerjaan rumah tangga dan kelebihan beban rumah tangga yang menunjukkan tingkat tekanan darah sistolik yang secara signifikan dan jauh lebih tinggi, menunjukkan interaksi penting antara pekerjaan rumah tangga dan job strain. ${ }^{19}$ penelitian ini dibuktikan oleh penelitian lain bahwa paparan gabungan terhadap ketegangan pekerjaan dan tuntutan keluarga yang tinggi, yang diwakili oleh tanggung jawab rumah tangga dan memiliki anak, menghasilkan hubungan yang lebih kuat pada tekanan darah daripada terpapar salah satu faktor ini secara terpisah. Hasil serupa diperoleh oleh Aquino. ${ }^{19}$

Stress terkait hipertensi dijelaskan oleh mekanisme peran stresor psikososial terhadap kejadian hipertensi juga bergantung pada faktor-faktor yang berhubungan dengan pekerjaan itu sendiri, yaitu kondisi kerja, lingkungan kerja, dan ketidakamanan kerja. Lingkungan kerja dan interaksi antara rekan kerja juga secara signifikan berkontribusi pada kejadian hipertensi. Faktor kerja organisasi mempengaruhi terjadinya hipertensi terlepas dari faktor kerja di tingkat individu, yaitu beban kerja dan stres kerja. stres kumulatif di tempat kerja dapat memprediksi peningkatan kadar tekanan darah. ${ }^{16}$

Penelitian ini didukung oleh penjelasan mengenai hubungan yang masuk akal antara ketegangan pekerjaan di tempat kerja dan hipertensi arteri dijelaskan oleh efek stres psikososial pada dinamika neuroendokrin. Paparan stres psiko-emosional yang konstan menyebabkan hiperaktivitas sistem saraf simpatis dan disfungsi sumbu hipotalamus-hipofisisadrenal, dengan pelepasan noradrenalin dan adrenalin dalam konsentrasi tinggi di celah sinaptik dan di aliran darah, yang masing-masing menyebabkan peningkatan jangka panjang dan persisten tekanan darah. ${ }^{74}$ aktivitas saraf simpatis dapat meningkat pada kondisi stres sehingga dapat membuat meningkatnya tekanan darah secara bertahap yang berarti semakin tinggi tingkat stres seseorang maka semakin tinggi pula tekanan darahnya. Apabila kondisi stres terjadi secara berkepanjangan tekanan darah dapat menjadi tetap atau semakin tinggi. ${ }^{26}$

Perawat, dokter maupun pekerjaan lain yang mengalami stres kerja akan memiliki risiko yang lebih tinggi untuk mengalami hipertensi. Sesuai dengan penelitian Mezuk B, dkk. Selain profesi tersebut terdapat juga penelitian yang memiliki resiko hipertensi karena tingkat stres yang tinggi berdasarkan penelitian Satmayani S, dkk. Ditemukan stress kerja yang tinggi kepada 6 kelompok professional yaitu dokter, insinyur, agen asuransi jiwa, pengacara, perawat dan guru. Tenaga kesehatan merupakan salah satu profesi paling menantang yang disebabkan oleh adanya tuntutan untuk melibatkan fisik dan mental sang individu. Berdasarkan uraian di atas, kesimpulan pada penelitian ini dapat terlihat bahwa stres kerja berhubungan dengan terjadinya hipertensi pada tenaga kesehatan.

\section{Keterbatasan}

Metoda pengambilan data tekanan darah yg tidak seragam serta data populasi yg tidak homogen dari sex, usia, jenis pekerjaan. Kedua literature review ini tidak menganalisis berbagai karakteristik subjek yang digunakan dalam penelitian yang dianalisis. Hal ini tidak dilakukan karena tidak semua penelitian mencantumkan secara lengkap karakteristik subjek penelitiannya, sehingga penulis menganggap analisis karakteristik subjek tidak tepat bila dilakukan. ketiga, literature review ini menggunakan metode penelitian dengan jenis penelitian yang sangat variatif.

\section{Simpulan dan saran}

Berdasarkan pembahasan dalam penelitian ini, peneliti menyimpulkan terdapat hubungan antara stres kerja dengan hipertensi pada tenaga kesehatan. Oleh sebab itu Bagi tenaga kesehatan disarankan untuk melakukan manajemen stres dengan baik serta bagi manajemen rumah sakit agar dapat membuat kebijakan dan penanganan stres pada tenaga kesehatan demi kesejahteraan dan kesehatan karyawan.

\section{Ucapan Terimakasih}

Penulis mengucapkan terimakasih kepada yang terhormat Dekan Fakultas Kedokteran Unisba Islam Bandung, pembimbing dan yang terlibat dalam penelitian ini sehingga penulis dapat menyelesaikan penyusunan scoping review ini.

\section{Daftar Pustaka}

1. Tedjasukmana P. Tata Laksana Hipertensi. Cdk [Internet]. 2012;39(4):251-5. Available from: https://s3.amazonaws.com/academia. edu.documents/38613408/o6_192Tata_ Laksana_Hipertensi.pdf?responsecontent-disposition =inline \% 253 B filename\%253DHipertensi.pdf\&X-AmzAlgorithm=AWS4-HMAC-SHA256\&X-Amz-Cred ential=AKIAIWOWYYGZ2Y53UL3A\%252F2020 0107\%252Fus-east

2. Biro Komunikasi dan Pelayanan Masyarakat KKR. Hipertensi Penyakit Paling Banyak Diidap Masyarakat [Internet]. Jumat, 17 Mei 2019. 2019. Available from: https://www.depkes.go.id/ article/view/19051700002/hipertensi-penyakitpaling-banyak-diidap-masyarakat.html

3. WHO. Hypertension [Internet]. 13 September 2019. 2019. Available from: https://www.who. int/news-room/fact-sheets/detail/hypertension

4. Kementerian Kesehatan RI Badan Penelitian dan Pengembangan. Hasil Utama Riset Kesehatan Dasar. Kementrian Kesehat Republik Indones [Internet]. 2018;83-8. Available from: http:// www.depkes.go.id/resources/download/infoterkini/hasil-riskesdas-2018.pdf

5. Indonesia KKR. Hari Hipertensi Dunia 2019: "Know Your Number, Kendalikan Tekanan Darahmu dengan CERDIK." [Internet]. 17 mei 
2019. 2019. Available from: http://p2ptm.kemkes. go.id/kegiatan-p2ptm/pusat-/hari-hipertensidunia-2019-know-your-number-kendalikantekanan-darahmu-dengan-cerdik

6. Nelwan JE, Sumampouw O. Pengaruh Penyuluhan Kesehatan Terhadap Pengetahuan Masyarakat Tentang Hipertensi di Kota Manado. 2019;(July).

7. Mezuk B, Kiarri, Kershaw, Hudson D, Kyuang RJS. Workplace Discrimination, and Hypertension Among Older Workers. 2011;3:38-50.

8. Romadhoni RD, Pudjirahardjo WJ. Beban Kerja Obyektif Tenaga Perawat di Pelayanan Rawat Inap Rumah Sakit. J Adm Kesehat Indones. 2016;4(1):57.

9. A, Mintjelungan DL, Rattu AJM, Kairupan BHR, Universitas P, Ratulangi S. Stres kini telah masalah yang umum pada kehidupan modern, termasuk stres yang berhubungan dengan pekerjaan (ILO , 2016). Stres kerja adalah respon fisik dan emosional yang berbahaya dan dapat terjadi ketika tuntutan pekerjaan yang ada melebihi kemampua. 2019;8(3):19-34. Available from: https://ejournal.unsrat.ac.id/index.php/kesmas/ article/view/23940/23594

10. Aslam HD, Mansoor N, Suleman Q. Analysis of Level of Stress among Doctors in Public and Private Hospitals of Pakistan. Int J Leaning Dev. 2013;3(2):109-35.

11. Jobplanet. 10 Profesi di Indonesia dengan Tingkat Kepuasan Kerja Paling Tinggi. jobplanet. 2016.

12. Search. VW\& C. No Title. Minneapolis: VITAL WorkLife. 2015.

13. kurnia K. Pengaruh Beban Kerja Fisik Dan Mental Terhadap Stres Kerja Pada Perawat Di Instalasi Gawat Darurat (IGD) RSUD Cianjur. 2012;1(2):767-76. Available from: https://www. neliti.com/publications/18807/pengaruh-bebankerja-fisik-dan-mental-terhadap-stres-kerjapada-perawat-di-insta

14. Rosnawati MR. the bahasa melayu version of the nursing stress scale among nurses: A re-liability study in Malaysia. Asia-Pacifc Journal of Public Health. 2010;22(4):501-506. Available from: https://doi.org/10.1177/1010539510380560

15. Satmayani S, Syahrul S, Saleh A. Stres Kerja Pada Perawat di Ruang Perawatan Pediatrik. J Keperawatan Muhammadiyah. 2018;3(2):101-9.

16. De Gaudemaris R, Levant A, Ehlinger V, Hérin F, Lepage B, Soulat JM, et al. Blood pressure and working conditions in hospital nurses and nursing assistants. The ORSOSA study. Arch Cardiovasc Dis. 2011;104(2):97-103.

17. Figueiredo AE, Urbanetto $\mathrm{J}$ de $\mathrm{S}$, Magnago TSB de S, Poli-de-Figueiredo CE. Psychosocial stress and hypertension in nursing staff. Clin Nurs Stud. 2015;3(4):15-20.

18. Gupta S. Self-perceived occupational stress and blood pressure profile of nurses from government hospitals. Int J Med Sci Public Heal. 2017;6(1):180.

19. Portela LF, Rotenberg L, Pereira Almeida AL, Landsbergis P, Griep RH. The influence of domestic overload on the association between job strain and ambulatory blood pressure among female nursing workers. Int J Environ Res Public Health. 2013;10(12):6397-408.

20. Merlin Cheema, Roopanshi Mishra, Shweta Rao, Monika Lal NM. WORK RELATED STRESS PERCEPTION \& HYPERTENSION AMONG NURSES WORKING AT SELECTED ICUS IN SGPGIMS, LUCKNOW, INDIA. INDIAN J Appl Res. 2019;(12):9-10.

21. Owolabi AO, Owolabi MO, OlaOlorun AD, Olofin A. Work-related stress perception and hypertension amongst health workers of a mission hospital in Oyo State, south-western Nigeria. African J Prim Heal Care Fam Med. 2012;4(1):1-7.

22. Portela LF, Griep RH, Landsbergis P, Rotenberg L. Self-reported hypertension and job strain in nursing personnel: Assessing two different formulations of the demand-control model. Clin Nurs Stud. 2015;3(2).

23. Adriano Marçal Pimenta AÁA. Job strain and arterial hypertension in nursing professionals from the municipal healthcare network in Belo Horizonte, Minas Gerais, Brazil. Rev Bras Saúde Ocup. 2016;41:1-11.

24. Lamy S, De Gaudemaris R, Lepage B, Sobaszek A, Caroly S, Kelly-Irving M, et al. Psychosocial and organizational work factors and incidence of arterial hypertension among female healthcare workers: Results of the Organisation des Soins et Santé des Soignants cohort. J Hypertens. 2014;32(6):1229-36.

25. Nedić O, Belkić K, Filipović D, Jocić N. Job Stressors among Female Physicians: Relation to Having a Clinical Diagnosis of Hypertension. Int $\mathrm{J}$ Occup Environ Health. 2010;16(3):330-40.

26. Rosenthal $\mathrm{T}$, Alter A. Occupational stress and hypertension. J Am Soc Hypertens. 2012;6(1):222. 